\title{
FAKTOR- FAKTOR PENYEBAB KONFLIK INTERPERSONAL SISWA DAN UPAYA PENANGGULANGANNYA
}

\author{
Oleh: \\ Wa Eni ${ }^{1)}$, Jahada ${ }^{2)}$ \\ 1) 2) Jurusan Bimbingan dan Konseling \\ Fakultas Keguruan dan Ilmu Pendidikan, Universitas Halu Oleo \\ Email: 1)eniummuqonita@gmail.com ${ }^{2)}$ jahadasahabudin77@gmail.com
}

\begin{abstract}
ABSTRAK
Penelitian ini bertujuan untuk mengetahui faktor- faktor penyebab konflik Interpersonal siswa dan upaya penanggulangannya. Penelitian ini adalah penelitian kualitatif dengan jenis penelitian studi kasus. Informan dalam penelitian ini berjumlah 8 orang yaitu 1 orang guru BK, Kepala Sekolah, 1 orang wali kelas dan 5 orang siswa. Data dikumpulkan dengan menggunakan metode wawancara dan dokumentasi. Metode analisis data menggunakan metode analisis deskriptif kualitatif model Miles dan Huberman. Hasil penelitian ini menunjukan bahwa faktor- faktor penyebab konflik interpersonal siswa adalah (1) faktor Internal yaitu mudah tersinggung, tidak mampu mengendalikan emosi, kesalah pahaman dan ingin diakui. dan (2) faktor Eksternal yaitu faktor lingkungan keluarga, faktor lingkungan sekolah dan faktor lingkungan pergaulan, Sementara upaya penanggulangan konflik interpersonal tersebut adalah menggunakan layanan informasi dan layanan mediasi.
\end{abstract}

\section{Kata Kunci: Konflik Interpersonal}

\section{FACTORS CAUSING THE STUDENTS INTERPERSONAL CONFLICT AND ITS EFFORT}

\begin{abstract}
The purpose of the research was to find out factors causing the students interpersonal conflict and its effort. The was qualitative research by doing case study. The Informants of the study were 5 people which include 1 guidance and counseling teacher, a head master, 1 homeroom teacher, and 5 students. The data were collected through interview and documentation. The data were analyzed by Miles and Huberman, descriptive qualitative model. The findings of the research show that the factors that cause the students interpersonal conflict are as follows: (1) internal factor like easy to be offended, unable to control him/her emotion, miss understanding, and are willing to be recognized, and (2) Eksternal include family environment, school enviromment, school environment, and sosial environment. There are two thigs to do when it comes to deal with the students interpersonal conflicts such as information sevice nd mediation service.
\end{abstract}

\section{Keywords: Interpersonal Conflict}




\section{Pendahuluan}

Konflik merupakan suatu kondisi ketidakcocokan obyektif antara nilai-nilai atau tujuan-tujuan, seperti perilaku yang secara sengaja mengganggu upaya pencapaian tujuan dan secara emosional mengandung suasana permusuhan. Konflik dapat dialami oleh setiap individu, antar individu maupun antar organisasi. Konflik sudah menjadi hal yang lumrah dan tidak dapat dihindarkan namun dapat diredam dan diselesaikan. Menurut Gibson, et al (dalam Shalihin, 2013: 11) hubungan selain dapat menciptakan kerja sama, hubungan saling tergantung dapat pula melahirkan konflik. Konflik dilatar belakangi oleh perbedaan ciri-ciri yang di bawa individu dalam suatu interaksi. Perbedaanperbedan tersebut di antaranya adalah menyangkut ciri fisik, kepandaian, pengetahuan, adat istiadat, keyakinan dan lain sebagainya.

Lingkungan lembaga pendidikan kerap terjadi konflik yang dapat menghalangi atau menghambat kepentingan orang lain utamanya antar siswa. Konflik yang sering terjadi di sekolah adalah konflik interpersonal sebagaimana yang diungkapkan oleh Campbell, R.F, et the most common and fisible type of conflict in school as well as other organization is interpersonal conflict, (Safitri dan Purwoko 2013: 155).

Wood dalam Setyana (2012: 146) menjelaskan konflik merupakan hal yang wajar dan tidak dapat dihindari dalam hubungan individu. Artinya konflik dapat terjadi dan akan dialami oleh siapa pun akan tetapi konflik pada siswa lebih kompleks dan sering terjadi. Seperti halnya konflik interpersonal yang terjadi di lingkungan sekolah dimana tempat berkumpulnya siswa dengan berbagai budaya dan kebiasaan yang berbeda. Oleh karena itu, kesenjangan antar individu tidak dapat dihindari .

Walgito (dalam Arisuzanti dan Purwoko, 2015: 2) menyebutkan konflik interpersonal juga disebut sebagai konflik antar pribadi. Konflik interpersonal atau konflik antar pribadi merupakan suatu situasi dimana tindakan seseorang berakibat menghalangi, menghambat dan mengganggu tindakan orang lain. Konflik interpersonal dapat terjadi bila mana antar individu mengalami perbedaan pendapat atau ide, sudut pandang, status sosial, ekonomi, budaya, bahasa dan kebiasaan yang berbeda sehingga menimbulkan pertentangan atau percekcokan dan ketidaksesuaian dalam mencapai tujuan yang diinginkan.
Konflik di kalangan siswa sudah menjadi fenomena umum di masyarakat. Konflik siswa merupakan pertentangan yang dialaminya, pertentangan ini bisa berbentuk pertentangan fisik dan non fisik yang pada umumnya berkembang dari pertentangan non fisik menjadi benturan fisik, yang bisa berkadar tinggi dalam bentuk kekerasan, bisa juga berkadar rendah yang tidak menggunakan kekerasan.

Kurniawan (2019) menampilkan fakta bahwa tawuran pelajar antar pemuda di Tanggerang menyebabkan lima pelajar tewas dan lima lainnya menderita cacat seumur hidup. Kasat Reskrim Polres Tanggerang selatan menyatakan bahwa selama tahun 2018, sedikitnya ada beberapa kasus tawuran menonjol yang terjadi di Tanggerang Selatan yang disebabkan hanya karena persoalan kecil yaitu saling ejek di sosial media, yang didominasi oleh pelajar atau anak- anak. Kasus lainnya juga terjadi di Jalan Bintaro pada tanggal 2 Desember 2018 yang menewaskan satu pelajar dan lainnya menderita cacat serta Sembilan orang diamankan. Pelakunya rata rata pelajar tingkat menengah yaitu SMP dan SMA. (https://metro.sindonews.com).

Dari beberapa kasus tersebut, dapat disimpulkan bahwa konflik interpersonal dapat menimbulkan masalah yang lebih fatal, padahal penyebabnya hanya dilatar belakangi oleh masalah masalah sepele, hal ini menunjukkan apabila konflik interpersonal siswa tidak mendapatkan penanganan maka dikhawatirkan akan terjadi seperti kasus di atas dan langkah awal penanganan suatu masalah adalah mengetahui penyebabnya.

Aminati (2013: 223) mengemukakan bahwa konflik interpersonal yang terjadi di sekolah dapat melibatkan siswa, guru, kepala sekolah dan orang tua. Sebagaimana siswa pada umumnya yang rawan terlibat konflik, siswa Sekolah Menengah Pertama (SMP) Negeri 5 Kendari juga mengalami hal yang sama yaitu banyak siswa yang terlibat konflik interpersonal. Konflik interpersonal yang terjadi pada akhirnya menghambat perkembangan siswa dalam belajar maupun sosial. Pada umumnya, konflik interpersonal yang tidak selesai menimbulkan jarak di antara siswa yang terlibat konflik interpersonal, bahkan melebar menjadi perpecahan kelompok.

Berdasarkan studi awal yang dilakukan peneliti di SMP Negeri 5 Kendari melalui wawancara dengan guru Bimbingan dan Konseling (BK) dapat diketahui bahwa konflik yang sering terjadi adalah konflik interpersonal. Percekcokan 
terjadi karena saling ejek, memanggil dengan sebutan nama binatang, menyebut nama orang tua dengan sebutan lucu, saling sindir lewat status di media sosial, hal ini menimbulkan reaksi berupa perasaan marah dan tidak terima bagi siswa yang dituju sehingga menyebabkan perkelahian bahkan tawuran antar kelas. Hal ini diperkuat dengan data yang terdapat dalam buku kasus siswa yang terdapat di sekolah SMP Negeri 5 Kendari. Di dalam buku kasus tersebut terdapat beberapa siswa yang tercatat berselisih paham, memasang status negatif, memaki dengan bahasa kotor, menyindir teman di sosial media dan mengejek nama orang tua dengan sebutan lucu, berkelahi dan ikut tawuran. Hal- hal tersebut membuat pihak yang dituju tidak menerima sehingga timbul konflik baik secara fisik maupun non fisik. Konflik fisik yaitu siswa berkelahi sedangkan konflik non fisik siswa tidak saling bertegur sapa. Menurut pernyataan salah satu guru Bimbingan dan konseling, bahwa permasalahan itu sudah sering diatasi dengan mempertemukan siswa yang berkonflik tersebut (layanan mediasi) namun pada akhirnya terjadi lagi.

Permasalahan-permasalahan siswa terutama konflik interpersonal dapat menimbulkan dampak negatif apabila dibiarkan terus menerus bahkan akan mempengaruhi hubungan antar siswa di sekolah sehingga penting untuk diketahui faktorfaktor penyebab konflik interpersonal siswa tersebut.

Berdasarkan hasil wawancara pra penelitian yang dilakukan oleh peneliti kepada guru Bimbingan dan Konseling di SMP Negeri 5 Kendari, konflik interpersonal siswa yang terjadi sudah sering diatasi namun masih saja terjadi, hal ini dibuktikan dengan catatan di buku kasus siswa sehingga peneliti menduga masih ada faktor lain yang menjadi penyebab terjadinya konflik interpersonal siswa tersebut. Oleh karena itu, peneliti tertarik melakukan penelitian dengan judul "Faktor-faktor Penyebab Konflik Interpersonal Siswa di SMP N 5 Kendari dan Upaya Penanggulangannya". Tujuan dari penelitian ini adalah untuk mengetahui faktor-faktor penyebab konflik interpersonal siswa dan upaya penanggulangannya.

Wirawan (2009: 55-59) menjelaskan bahwa konflik banyak jenisnya dan dapat dikelompokan berdasarkan altar terjadinya konflik, pihak yang terkait dalam konflik dan substansi konflik. Salah satunya adalah konflik personal dan konflik interpersonal. Konflik personal adalah konflik yang terjadi dalam diri seorang individu karena harus memilih dari sejumlah alternatif pilihan yang ada atau karena memunyai kepribadian ganda. Sedangkan konflik interpersonal adalah konflik yang terjadi di dalam suatu organisasi atau konflik di tempat kerja, konflik yang terjadi di antara mereka yang bekerja untuk suatu organisasi.

Dayakisni \& Hudaniah (dalam Bilqis \& Purwoko, 2012: 239) menyebutkan konflik interpersonal adalah konflik antar pribadi yang dikarenakan adanya pertentangan kepentingan atau ketidaksepakatan pendapat yang menyebabkan tindakan atau tujuan seseorang terhambat oleh tindakan orang lain. Selanjutnya, Johnson (dalam Arisuzanti \& Purwoko, 2015: 2) berpendapat bahwa konflik interpersonal atau konflik antar pribadi merupakan suatu situasi dimana tindakan seseorang berakibat menghalangi, menghambat dan mengganggu tindakan orang lain. Konflik interpersonal dapat terjadi bila mana antar individu mengalami perbedaan pendapat atau ide, sudut pandang, status sosial, ekonomi, budaya, bahasa dan kebiasaan yang berbeda sehingga menimbulkan pertentangan/ percekcokan dan ketidak sesuaian dalam mencapai tujuan yang diinginkan.

Setyana (2012 :147) menyebutkan konflik interpersonal yaitu suatu kondisi yang terdapat perbedaan antar individu sehingga menimbulkan ketidakcocokkan dan ketidaknyamanan pada keduanya sehingga dapat disimpulkan bahwa konflik interpersonal siswa adalah pertentangan atau perselisihan antar siswa yang satu dengan siswa yang lainnya. Pertentangan ini sering disebabkan karena adanya perbedaan pandangan, perbedaan kepribadian, sudut pandang, status sosial, ekonomi, budaya, bahasa dan kebiasaan yang berbeda.

Wijono (dalam Purwoko, 2013: 375) menyatakan bahwa konflik interpersonal disebabkan oleh beberapa faktor yaitu: 1) adanya kesalahan dalam presepsi, 2) kesalahan dalam berpendapat, 3) kesalahan dalam memahami, 4) kesalahan dalam berkomunikasi, 5) perbedaan tujuan, 6) perbedaan nilai-nilai, 7) latar belakang budaya, 8) sosial-Ekonomi dan, 9) sifat-sifat pribadi.

Sebelumnya, Kartono (2011) mengemukakan bahwa faktor- faktor penyebab konflik interpersonal siswa adalah: 
1. Faktor Internal

a. Reaksi Frustasi Negatif

Dengan semakin pesatnya usaha pembangunan, modernisasi, urbanisasi dan industrialisasi yang berakibat semakin kompleksnya masyarakat sekarang, semakin banyak pula anak remaja yang tidak mampu melakukan penyesuaian diri terhadap berbagai perubahan sosial itu. Mereka lalu mengalami banyak kejutan, frustasi, konflik terbuka baik eksternal maupun internal, ketegangan batin dan gangguan kejiwaan. Apalagi ditambah oleh semakin banyaknya tuntutan sosial, sanksisanksi dan tekanan sosial/ masyarakat yang mereka anggap melawan dorongan kebebasan mutlak dan ambisi mereka yang sedang mengebu-gebu.

b. Gangguan Pengamatan dan Tanggapan. Adanya kedua gangguan tersebut sangat menganggu daya adaptasi dan perkembangan pribadi anak yang sehat. Gangguan pengamatan dan tanggapan itu antara lain berupa: ilusi, halusinasi dan gambaran semu (waanvoorstelling), Sebagai akibat jauhnya, anak-anak remaja ada yang berubah menjadi agresi dan eksplosif menghadapi segala macam "takanan dan bahaya dari luar". Karena itu reaksinya berupa: cepat naik darah, cepat bertindak menyerang dan berkelahi.

c. Gangguan Cara Berpikir. Berfikir mutlak perlu bagi kemampuan orientasi yang sehat dan adaptasi wajar terhadap tuntutan lingkungan. Berfikir juga penting bagi upaya memecahkan kesulitan dan permasalahan hidup sehari-hari. Jika anak remaja tidak mampu mengoreksi fikiran-fikirannya yang salah dan tidak sesuai dengan realita yang ada, maka fikirannya terganggu ia kemudian dihadapi bayangan semu yang palsu. Anak yang sehat pasti mampu membetulkan kekeliruan sendiri dengan jalan: berpikir logis dan mampu membedakan fantasi dari kenyataan.

d. Gangguan Emosional/ Perasaan. Perasaan memberikan nilai pada situasi kehidupan dan menentukan sekali besar kecilnya kebahagian serta rasa kepuasan. Perasaan bergandengan dengan pemuasan terhadap harapan, keinginan dan kebutuhan manusia. Jika semua tadi terpuaskan, orang merasa senang dan bahagia; sebaliknya jika keinginan dan kebituhannya tidak terpenuhi, ia mengalami kekecewaan dan banyak frustasi.
2. Faktor Eksternal

a. Lingkungan Keluarga, keluarga merupakan lembaga pertama dan utama dalam melakukan proses sosialisasi dan sivilisasi pribadi anak. Di tengah keluarga anak belajar mengenal makna kasih sayang, simpati, loyalitas, ideologi, bimbingan dan pendidikan. Keluarga memberikan pengaruh menentukan pada pembentukan anak dan pribadi anak dan menjadi unit sosial terkecil yang memberikan fondasi primer bagi perkembangan anak. Baik buruknya struktur keluarga memberikan dampak baik atau buruknya, perkembangan jiwa dan jasmani anak.

b. Lingkungan Sekolah, lingkungan sekolah yang tidak merangsang siswanya untuk belajar (misalnya susasana kelas yang monoton, peraturan yang tidak relevan dengan pengajaran, tidak adanya fasilitas praktikum dan sebagainya) akan mengakibatkan siswa lebih senang melakukan kegiatan di luar sekolah bersama teman-temannya. Guru memegang peranan penting. Sayangnya guru lebih berperan sebagai penghukum dan pelaksana aturan serta sebagai tokoh otoriter yang sebenarnya juga menggunakan cara kekerasan (walau dalam bentuk berbeda) dalam mendidik siswanya.

c. Mileu. Mileu atau lingkungan sekitar tidak selalu baik dan menguntungkan bagi pendidikan dan perkembangan anak. Sebaliknya adakalanya lingkungan dihuni oleh orang dewasa serta anak-anak muda kriminal dan anti sosial yang bisa merangsang timbulnya reaksi emosional buruk pada anak anak puber dan adolesens yang masih labil jiwanya. Dengan begitu anak-anak remaja ini akan mudah terjangkit pola kriminal asusila dan anti sosial tadi. Jiwa para remaja itu amal labil.

Berdasarkan uraian di atas, maka dapat disimpulkan bahwa faktor-faktor penyebab individu melakukan konflik yaitu faktor intern dan faktor ekstern. Faktor internal meliputi reaksi frustasi negatif, gangguan pengamatan dan tanggapan, gangguan cara berpikir, gangguan emosional atau perasaan. Sedangkan faktor eksternal meliputi lingkungan keluarga, lingkungan sekolah dan milieu.

Selanjutnya, dalam mengatasi persoalan konflik interpersonal, beberapa langkah yang dapat 
dilakukan oleh seorang guru BK antara lain sebagai berikut:

1. Layanan Informasi

Hallen dalam Abidin \& Budiyono (2010: 40-41) layanan informasi ialah layanan bimbingan dan konseling yang memungkinkan klien menerima dan memahami berbagai informasi (informasi pendidikan, jabatan karir) yang dapat digunakan sebagai bahan pertimbangan dan pengambilan keputusan dan kepentingan individu. Layanan ini juga bertujuan agar individu (siswa) memahami informasi dengan segala seluk beluknya, penguasaan informasi dapat mencegah timbulnya masalah, pemecahan suatu masalah untuk memelihara dan mengembangkan potensi individu serta memungkinkan individu yang bersangkutan dapat membuka diri dalam mengaktualisasikan hak haknya.

2. Layanan Mediasi

Prayitno (dalam Abidin dan Budiyono, 2010: 101) layanan mediasi adalah proses pemberian bantuan kepada klien, individu dan kelompok, untuk mendapatkan tujuan dan menyelesaikan masalah yang dihadapi oleh klien. Layanan ini bertujuan untuk mencapai kondisi hubungan yang positif dan kondusif di antara para klien yaitu pihak-pihak yang berselisih dan memfokuskan pada perubahan kondisi menjadi lebih baik dari kondisi awal.

Jadi dapat disimpulkan bahwa layanan informasi yang dapat memberikan pengaruh yang besar kepada siswa dalam menerima dan memahami informasi yang dapat dipergunakan sebagai bahan pertimbangan dan pengambilan keputusan. Layanan mediasi bertujuan untuk memperbaiki hubungan di antara siswa yang sedang berkonflik dan dapat diaktulisasikannya hubungan yang positif, kondusif, sehingga dirasakan membahagiakan dan memberikan manfaat bagi pihak-pihak yang terkait.

\section{Metode Penelitian}

Penelitian ini dilaksanakan di SMP Negeri 5 Kendari yang beralamat di Jalan Gersamata, Kelurahan Anduonohu Kecamasan Poasia selama 3 (tiga) bulan.

Jenis penelitian ini adalah penelitian kualitatif dengan jenis studi kasus yang bertujuan untuk menggambarkan atau mengetahui secara mendalam mengenai faktor-faktor penyebab konflik interpersonal siswa di SMP Negeri 5 Kendari dan upaya peanggulanganya.
Pengumpulan data dalam penelitian ini menggunakan Wawancara dan Dokumentasi. Wawancara dilakukan untuk memperoleh informasi tentang faktor-faktor yang mempengaruhi konflik interpersonal siswa. Peneliti melakukan wawancara dengan Kepala Sekolah, 1 orang Guru BK, 1 orang Wali Kelas , 3 orang siswa yang memiliki konflik interpersonal dan 2 orang siswa yang tidak terlibat konflik interpersonal. Dokumentasi ditujukan untuk memperoleh data langsung di SMP Negeri 5 Kendari meliputi buku kasus relevan, laporan kegiatan, foto dan data relevan penelitian. Dokumentasi bertujuan mengumpulkan data-data siswa yang memiliki catatan pada buku kasus konflik interpersonal.

Analisis data dalam penelitian ini menggunakan analisis data kualitatif model Miles dan Hubberman yang terdiri dari 4 tahapan (dalam sugiyono, 2017: 133) yakni:

1. Data Collection (Pengumpulan Data)

Kegiatan pada setiap penelitian adalah mengumpulkan data dalam penelitian. Data yang diperoleh adalah data kualitatif. Data tersebut dianalisis dengan statistik dalam penelitian kualitatif pengumpulkan dengan observasi atau wawancara mendalam dan dokumentasi.

2. Data Reduction (Reduksi Data)

Reduksi data merupakan proses pemilihan, pemusatan perhatian pada penyederhanaan, pengabsahan dan transpormasi data "kasar" yang muncul dari catatan-catatan tertulis di lapangan. Tujuan penelitian dapat digunakan oleh peneliti sebagai acuan dalam mereduksi data sehingga data-data yang tidak sesuai dengan tujuan dapat direduksi. Dalam reduksi data merangkum pokok-pokok data yang diperoleh dari wawancara dan dokumentasi sehingga dapat memberikan gambaran yang jelas tentang faktor-faktor penyebab konflik interpersonal siswa dan upaya penanggulangannya.

3. Data Display (Penyajian Data)

Penyajian data merupakan sekumpulan informasi tersusun yang memberi kemungkinan adanya penarikan kesimpulan dan pengambilan tindakan. Melalui penyajian data, data terorganisasi, tersusun dalam pola hubungan sehingga dapat semakin mudah dipahami. Penyajian data ditampilkan dengan sekelompok informasi yang memberi kemungkinan adanya penarikan kesimpulan dan pengambilan 
tindakan yang mengarah pada tercapainya sebuah tujuan penelitia

4. Data Conclusion Drawing/ Verification (Penarikan Kesimpulan)

Kesimpulan dalam penelitian kualitatif diharapkan merupakan temuan baru yang dapat memberikan deskripsi atau gambaran suatu obyek yang sebelumnya masih remang-remang sehingga setelah diteliti menjadi jelas, dapat berupa hubungan kasual atau interaktif hipotesis atau teori.

\section{Hasil Penelitian dan Pembahasan \\ Hasil Penelitian}

Faktor penyebab konflik interpersonal siswa di SMP Negeri 5 Kendari yaitu:

1. Faktor Internal

a. Mudah Tersinggung

Hasil yang diperoleh dari informan bahwa salah satu masalah yang kerap muncul dalam relasi adalah mudah tersinggung yakni reaksi sedikit-sedikit tersinggung, sesuatu yang seharusnya tidak patut ditersinggungkan menjadi hal yang menimbulkan konflik. Siswa yang merasa tersingggung, akan menjadi tidak tenang dan marah, yang akhirnya melahirkan perselisihan yang berujung pada perkelahian.

b. Tidak Mampu Mengendalikan Emosi

Kurangnya kemampuan dalam mengendalikan emosi menjadikan siswa sering mengalami konflik dengan temannya. Ketika terjadi sesuatu keadaan yang tidak menyenangkan, misalnya adanya perbedaan pendapat atau adanya sikap yang tidak menyenangkan, karena saling ejek atau saling sindir, maka akan mendorong perubahan suasana hati seseorang menjadi marah, jengkel dan perasaan emosional lainnya.

c. Kesalah pahaman.

Individu pada umumnya memiliki karakteristik yang berbeda-beda. Perbedaan karakter dapat mewarnai komunikasi. Namun dalam kondisi tertentu interaksi akan menimbulkan konflik, misalnya ketika dua orang individu sedang berbicara walaupun tujuannya adalah hanya berupa candaan tetapi persepsi dari si penerima komunikasi tersebut salah, akan menjadi salah tangkap isi pesan sehingga hal tersebut dapat menjadi penyebab konflik yang terjadi. Dengan kata lain, konflik dapat terjadi, ketika adanya proses interaksi antara individu satu dengan individu yang lain, tetapi dalam hal ini pesan yang disampaikan oleh komunikan disalah artikan oleh si penerima sehingga konflik pun tidak dapat terhindar.

d. Ingin Diakui

Hasil yang diperoleh dari informan bahwa konfllik terjadi karena hanya ingin diakui dan tidak mau dipandang rendah oleh temantemannya.

2. Faktor Eksternal.

a. Faktor Lingkungan Keluarga

Keluarga merupakan lembaga pertama dan utama dalam melakukan proses sosialisasi pada anak. Keluarga memberikan pengaruh dalam pembentukan kepribadian anak. Baik buruknya kondisi keluarga juga memberikan dampak yang bagi perkembangan jiwa dan jasmani anak. Hal ini disebabkan karena lingkungan yang anak kenali untuk pertama kali adalah lingkungan keluarga, yaitu hubungannya dengan ayah dan ibunya atau anak dengan anggota keluarga lainnya. Anak yang bertindak negatif disebabkan oleh keluarga yang kurang harmonis. Sebagian orang tua tidak menyadari hal ini dan umumnya tidak peka terhadap perkembangan anaknya. Hal ini sering disebabkan oleh kesibukan mereka dalam mencari nafkah untuk menghidupi keluarganya sehingga si anak banyak dipengaruhi keadaan lingkungan yang tidak tersaring baik dan buruknya.

b. Faktor Lingkungan Sekolah

Hasil yang diperoleh dari informan bahwa konflik yang sering dilakukan oleh siswa di sekolah adalah perselisihan, ejekan kepada nama orang tua dengan panggilan lucu dan halhal lain yang dapat menimbulkan pertentangan dan perkelahian.

c. Faktor lingkungan pergaulan

Lingkungan pergaulan siswa yang tidak kondusif juga menjadi salah satu pemicu terjadinya konflik antar siswa. Lingkungan adakalanya dihuni oleh orang dewasa serta anak-anak muda kriminal dan anti sosial, yang bisa merangsang timbulnya reaksi emosional buruk pada anak- yang masih labil jiwanya. Dengan begitu anak-anak remaja ini muda terjangkit oleh pola kriminal, asusila dan anti sosial tadi. Jiwa para remaja itu amat labil. Jika mereka mendapatkan pengaruh buruk dengan perbuatan anti-sosial yang dilakukan oleh orang dewasa maka mereka dengan mudah akan 
terjangkit perilaku buruk tadi yang dijadikan sebagai kebiasaan.

Pernyataan-pernyataan di atas menunjukkan bahwa faktor penyebab konflik interpersonal siswa adalah faktor internal atau yang berasal dari dalam diri siswa, yaitu ketidakmampuan siswa dalam mengendalikan emosi, mudah tersinggung, kesalahpahaman dan perasaan ingin diakui oleh orang lain, salah satunya disebabkan siswa yang belum bisa mengendalikan emosi sehingga masalah-masalah yang sepeleh saja dapat menimbulkan suatu pertengkaran dan berakhir pada terjadinya perkelahian yang dapat mengancam jiwa siswa itu sendiri maupun orang lain selain dari faktor internal siswa juga dari faktor lingkungan keluarga di mana sebagian besar besar orang tua lebih sibuk dengan mengurus pekerjaannya dan keluarga yang tidak utuh (broken home) sehingga mereka kekurangan kasih sayang dan pada akhirnya mereka mencari cara lain untuk mendapatkan perhatian.

Faktor yang terakhir adalah faktor lingkungan sekolah dan lingkungan pergaulan siswa dimana faktor ini juga menjadi salah satu pemicu terjadinya suatu konflik antar siswa. Pengawasan dari pihak sekolah masih kurang serta dari faktor lingkungan pergaulan siswa yang lebih sering bergaul dengan orang-orang yang tidak baik yaitu pemuda yang sering minum-minuman keras atau bergaul dengan geng-geng yang biasa melakukan suatu tindakan yang menyimpang .

Selanjutnya, upaya penanggulangan konflik interpersonal berdasarkan hasil wawancara yang dilakukan oleh peneliti bahwa upaya penanggulangan konflik interpersonal di kalangan siswa SMP Negeri 5 kendari yaitu:

1. Layanan Informasi.

Layanan informasi bertujuan untuk memberikan pemahaman dan pengetahuan kepada siswa mengenai berbagai hal yang diperlukan selama proses belajar dan pembelajaran di sekolah. Layanan ini diupayakan sebagai bentuk bentuk pencegahan agar siswa tidak mengalami konlik. Layanan ini diberikan di dalam ruangan kelas pada saat jadwal belajar kosong dan di lapangan pada saat apel pagi yang diikuti oleh seluruh siswa. Informasi yang diberikan berupa nasehatnasehat tentang dampak dan hukuman bagi siswa yang terlibat dalam konflik. Tujuannya adalah agar siswa yang berkonflik tidak lagi melakukan atau hal-hal yang dapat menimbulkan konflik dan upaya pencegahan bagi siswa yang tidak memiliki konflik. Selain itu siswa juga diarahkan untuk mengikuti kegiatan ekstrakurikuler seperti OSIS dan PMR agar siswa dapat menyalurkan bakatnya dan membangun kerja sama yang baik.

2. Layanan mediasi. Layanan mediasi yang diberikan pihak sekolah khususnya guru bimbingan dan konseling dapat berupaya untuk mendamaikan siswa-siswa yang berkonflik. Layanan ini diberikan di ruangan bimbingan dan konseling, dengan mengikut sertakan siswa yang berkonflik, terkadang juga melibatkan orang tua siswa.

Adapun tujuan layanan medisi adalah terjadi perubahan atas kondisi awal yang negatif (bertikai atau bermusuhan) menjadi kondisi baru positif (kondusif dan bersahabat) dengan hubungan antara kedua belah pihak yang bermusuhan..

Jadi dapat disimpulkan bahwa upaya penanggulangan konflik interpersonal layanan informasi dan layanan mediasi terhadap siswa yang berselisih guru BK mengumpulkan peserta didik dalam satu ruangan dan menerima dengan baik serta berlaku adil tidak memihak kepada siapapun. Pihak sekolah juga mengarahkan siswa untuk mengikuti kegiatan ekstrakurikuler yang bertujuan untuk membangun hubungan kerja sama dan hubungan sosial yang baik dengan mengikuti kegiatan OSIS dan Pramuka.

\section{Pembahasan}

Faktor-faktor penyebab terjadinya konflik interpersonal siswa di SMP Negeri 5 Kendari, disebabkan oleh berbagai faktor. Faktor tersebut adalah faktor internal yaitu faktor yang berasal dari dalam diri siswa, yaitu tidak mampu mengendalikan emosi, mudah tersinggung, ingin diakui dan kesalahpahaman. Sedangkan faktor eksternal atau yang berasal dari luar diri siswa yaitu lingkungan keluarga, lingkungan sekolah maupun lingkungan sekitar siswa.

Faktor- faktor penyebab sehingga terjadi konflik interpersonal pada siswa SMP Negeri 5 Kendari adalah mudah tersinggung. Salah satu masalah yang kerap muncul dalam relasi adalah mudah tersinggung yakni reaksi sedikit-sedikit tersinggung, hal sepele yang seharusnya tidak patut ditersinggungkan menjadi hal yang menimbulkan konflik. 
Faktor selanjutnya yang menjadi penyebab siswa melakukan konflik adalah tidak mampu mengendalikan emosi. Gangguan emosional merupakan keadaan emosi yang tidak stabil, baik karena emosi yang timbul terlalu kuat dan mampu mendorong perubahan suasana hati seseorang menjadi marah, jengkel, ketika terjadi sesuatu yang tidak menyenangkan. Kurangnya kemampuan dalam mengendalikan Emosi menjadikan siswa sering mengalami konflik dengan temannya. Ketika terjadi sesuatu keadaan yang tidak menyenangkan, misalnya adanya perbedaan pendapat atau adanya sikap yang tidak menyenangkan, karena saling ejek atau saling sindir maka akan mendorong perubahan suasana hati seseorang menjadi marah, jengkel dan perasaan emosional lainnya.

Hasil dari penelitian ini hampir sama jika dikaitkan dengan hasil penelitian Setyono dan Ismanto (2015) yang menemukan bahwa salah satu faktor penyebab konflik interpersonal siswa adalah emosi siswa. Usia remaja dimana emosi pada usiausia tersebut sangat mudah terpengaruh oleh orang lain, karena pada usia pubertas tersebut emosi anak tidak labil sehingga mudah sekali emosinya naik dengan cepat. Hal ini juga diperkuat oleh pendapat Hurlock (dalam Lusiawati, 2013) bahwa emosi pada masa remaja sering kali meluap- luap tinggi dan emosi negatif mereka lebih mudah mucul.

Faktor internal selanjutnya yang menyebabkan terjadinya konflik interpersonal siswa di SMP Negeri 5 Kendari adalah Kesalahan pahaman. Antara pemberi dan penerima informasi tidak terjadi dengan baik. Hal ini menjadi penyebab adanya tekanan psikologi pada diri siswa sehingga memicu terjadinya konflik antar siswa. Individu pada umumnya memiliki karakteristik yang berbeda-beda, dalam hal ini individu yang sedang berinteraksi walaupun tujuannya itu hanya bercanda tetapi persepsi dari si penerima komunikasi tersebut salah, jadi kemungkinan besar hal itulah yang menjadi salah tangkap isi pesan. Dengan kata lain, konflik tersebut dapat terjadi, ketika adanya proses interaksi antara individu satu dengan individu yang lain, tetapi dalam hal ini pesan yang disampaikan oleh komunikan disalah artikan oleh si penerima sehingga konflik pun tidak dapat terhindar.

Hal ini sesuai dengan pernyataan yang diungkapkan oleh Gultung (dalam Hendrastin dan Purwoko, 2014: 366) menemukan prinsip mengenai studi konflik dan konflik interpersonal disebabkan oleh adanya pertentangan baik pandangan, tindakan maupun komunikasi yang berujung dengan kesalah pahaman. Hal ini juga diperkuat oleh pendapat Eggert (dalam Purwoko, 2013: 375) bahwa faktor penyebab konflik interpersonal adalah komunikasi yang buruk, ketidak cocokkan perilaku atau kebiasaan dan ketidak cocokan nilai- nilai.

Faktor selanjutnya yang menjadi penyebab konflik interpersonal siswa adalah perasaan siswa yang ingin diakui yaitu tidak ingin dipandang rendah atau dianggap remeh oleh orang lain. Ketika terjadi percekcokan, siswa melakukan pertahanan diri dengan melakukan perkelahian agar dianggap kuat dan berpengaruh sehingga tidak dianggap remeh oleh teman- temannya yang lain. Hal ini sesuai dengan pernyataan Mersi dan frick (dalam Anwar, 2015: 476) bahwa konflik pada remaja disebabkan oleh permasalahan dengan temannya sebagai upaya untuk melindungi diri dari kecemasannya maka remaja melakukan pertahanan dan eksternalisasi perilaku secara agresif, berbuat salah dan kenakalan lainnya. Hal tersebut juga didukung oleh pendapat Suardiman (dalam Pohan, 2015: 3) masalah wajar yang berhubungan dengan teman sebaya dan peranannya sebagai pria wanita pada remaja salah satunya adalah memunyai pikiran agar bisa diterima, populer dan menunjukkan kemampuan-kemampuannya dalam kelompok. Penerimaan kelompok terhadapnya dapat membuat remaja merasa diakui, dihargai dan selanjutnya mengembangkan kepercayaan dirinya untuk berperilaku dan berinteraksi dengan lingkungan sosialnya.

Berdasarkan penjelasan di atas, dapat disimpulkan bahwa siswa yang melakukan suatu konflik interpersonal, mereka mengaku bahwa mereka tidak ada kontrol di dalam diri sehingga sering salah paham, cepat emosi, mudah tersinggung dan ingin diakui teman temannya.

Untuk faktor eksterrnal, yang menjadi faktor penyebab konflik interpersonal siswa adalah lingkungan keluarga dimana sebagian besar orang tua lebih sibuk dengan mengurus pekerjaannya sehingga anak-anak tersebut kurang mendapatkan perhatian dari orangtua, adanya tekanan di dalam keluarga dan keluarga yang tidak utuh (broken home) sehingga mereka mencari perhatian dari teman. Seperti pernyatan salah satu informan, bahwa mereka kurang mendapatkan perhatian serta kasih sayang dari orang tuanya. Lain halnya dengan salah satu informan yang menyatakan bahwa dia selalu dipukul oleh orang tuanya kalau memiliki kesalahan dengan harapan bahwa 
anaknya tidak akan melakukan kesalahan lagi. Hal in tentu menjadi tekanan bagi anak sehingga ketika keluar pada lingkungan sosial mereka merasa bebas. Kebebasan inilah yang biasa membuat mereka melakukan apa saja sehingga biasanya melakukan hal-hal yang negatif.

Keluarga merupakan lembaga pertama dan utama yang dikenali anak. Di tengah keluarga anak belajar mengenal makna cinta, kasih sayang, perhatian serta pendidikan agama. Ayah sebagai pemimpin yang berperan sebagai pemimpin keluarga harus mampu mengarahkan dan mengontrol anak- anaknya serta ibu yang menjadi sekolah pertama bagi anak- anaknya dalam hal pemberian bimbingan ilmu agama sebelum anak mendapatkan pengaruh dari luar. Keluarga memberikan pengaruh menentukan pada pembentukan watak dan pribadi anak dan menjadi unit sosial terkecil yang memberikan fondasi primer bagi perkembangan anak. Hal tersebut sesuai dengan pernyataan salah satu informan bahwa kebanyakan siswa yang sering berkonflik berasal dari keluarga yang tidak harmonis, misalnya antar orang tua, orang tua dengan anak atau antara sesama anak sering bertengkar, maka anak akan mencari kenyamanan di luar rumah, nah di luar rumah itulah anak bisa saja berkawan dengan orang-orang yang tidak baik sehingga anak tersebut juga akan terpengaruh menjadi tidak baik. Oleh karena itu, keluarga memegang peranan penting bagi pertumbuhan dan perkembangan anak, selain itu kurangnya perhatian dan pengawasan dari orang tua karena keluarga yang broken. Kondisi tersebut didukung oleh pernyatan kartono (2011: 116) keluarga yang dipenuhi dengan kekerasan (entah antar orang tua atau pada anaknya) yang kemudian itu berdampak pada anak, anak akan belajar bahwa kekerasan adalah bagian dari dirinya sehingga adalah hal yang wajar kalau ia melakukan kekerasan pula. Sebaliknya, orang tua yang terlalu melindungi anaknya (over protective) ketika remaja akan tumbuh sebagai individu yang tidak mandiri dan tidak berani mengembangkan identitasnya yang unik. Begitu bergabung dengan teman-temannya, ia akan menyerahkan dirinya secara total terhadap kelompoknya sebagai bagian dari identitas yang dibangunnya.

Faktos selanjutnya adalah faktor lingkungan sekolah. Faktor ini juga menjadi salah satu pemicu terjadinya suatu konflik interpersonal siswa yaitu karena tempat dan kondisi sekolah yang menjadi peluang atau pemicu pelajar melakukan suatu perkelahian. Sekolah yang kecil dengan jumlah siswa yang banyak membuat pengawasan dari pihak sekolah masih kurang serta dari faktor lingkungan pergaulan siswa yang lebih sering bergaul dengan geng-geng atau kelompokkelompok yang biasa melakukan suatu tindakan yang menyimpang seperti tawuran. Selanjutnya, faktor lingkungan sekolah, dimana faktor ini juga menjadi salah satu pemicu terjadinya suatu konflik di kalangan siswa yaitu karena tempat dan kondisi sekolah dan kurangnya pengawasan dari pihak sekolah.

Faktor yang terakhir adalah lingkungan sekitar siswa. Lingkungan pergaulan siswa menjadi salah satu pemicu terjadinya suatu konflik yaitu dari faktor lingkungan pergaulan siswa yang lebih sering bergaul dengan orang-orang yang biasa sering meminum-minum atau mabukmabukkan atau bergaul dengan geng-geng atau kelompok-kelompok yang biasa melakukan suatu tindakan yang menyimpang seperti konflik interpersonal serta rasa solidaritas yang tinggi di antara pelajar. Seperti informan mereka ikut melakukan tawuran karena mereka ingin membantu temannya di dalam sebuah tawuran.

Jadi, ketika seorang anak telah berada di tengah-tengah lingkungan sosial dan bergaul dengan anak-anak yang tidak baik maka anak-anak tersebut juga akan melakukan atau mengikuti perbuatan-perbuatan yang kurang baik tersebut bahkan akan melakukan suatu tindakan kriminal. Jiwa kelompok ini menumbuhkan kerelaan berkorban dan semangat saling tolong-menolong pada setiap keadaan apa pun.

Hal tersebut didukung oleh pernyataan Hurlock (dalam Ramadhani, 2016: 189) tahapan tersulit bagi remaja adalah penyesuaian sosialnya. Remaja kerap bingung dengan peran dan tuntutan harapan masyarakat di dekatnya. Dalam perkembangan sosial remaja, mereka cenderung akan menjauhi orang tua sebagai keinginan kebebasan emosional akan dirinya dan lebih dekat teman sebaya akan kesamaan peran dalam diri mereka. Hubungan dalam keluarga akan menentukan remaja membentuk pola pikir sedangkan untuk $40 \%$ waktu remaja dihabiskan untuk berkumpul dengan teman sebaya. Sehingga dapat disimpulkan bahawa anak akan cenderung lebih senang berkumpul dengan temannya dari pada dengan keluarganya apa lagi jika orang tua terlalu sibuk dan tidak memerhatikan anakanaknya. 
Upaya penanggulangan konflik interpersonal di SMP Negeri 5 Kendari menurut Guru Bimbingan dan Konseling terdapat beberapa jenis layanan adalah layanan informasi dan layanan mediasi. Layanan informasi merupakan suatu layanan yang berupaya memenuhi kekurangan individu akan informasi yang mereka perlukan. Individu memerlukan berbagai informasi baik untuk keperluan kehidupannya sehari-hari, sekarang maupun untuk perencanaan kehidupannya ke depan. Individu bisa mengalami masalah dalam kehidupannya sehari-hari maupun kehidupannya di masa depan sedangkan layanan mediasi merupakan layanan konseling yang dilaksanakan konselor terhadap dua pihak (atau lebih) yang sedang dalam keadaan saling tidak menemukan kecocokan. Ketidak cocokan menjadikan mereka saling bertentangan dan bahkan bermusuhan. Pihak-pihak yang bertentangan itu jauh dari rasa damai bahkan mungkin berkehendak saling menghancurkan.

Dengan adanya layanan mediasi, Guru Bimbingan dan Konseling berusaha mengantarai atau sebagai mediator di antara dua pihak yang saling berseselisih. Jadi layanan mediasi yakni layanan yang memungkinkan permasalahan atau perselisihan yang dialami klien dengan pihak lain dapat terentaskan dengan konselor sebagai mediator.

\section{Kesimpulan dan Saran Kesimpulan}

Berdasarkan hasil penelitian maka yang menjadi kesimpulan dalam penelitian ini adalah faktor- faktor penyebab konflik interpersonal siwa di SMP Negeri 5 Kendari adalah faktor dari dalam diri siswa seperti: siswa mudah tersinggung, siswa tidak mampu mengendalikan emosi, kesalahpahaman dan ingin diakui oleh orang lain. Faktor dari luar diri siswa yaitu faktor keluarga yakni kehidupan keluarga yang tidak harmonis, kurangnya perhatian orang tua, faktor lingkungan sekolah dan faktor lingkungan pergaulan (mileu). Sedangkan upaya penanggulangannya adalah dengan menggunakan layanan informasi sebagai bentuk pencegahan dan layanan mediasi sebagai bentuk pengentasan.

\section{Saran}

1. Bagi kepala sekolah agar kiranya berupaya untuk mewujudkan lingkungan sekolah yang aman, nyaman dan kondusif serta mampu bekerja sama dengan seluruh personil sekolah.
2. Bagi guru BK kiranya bisa berkoordinasi dengan guru mata pelajaran, kepala sekolah dan orang tua siswa dalam membimbing dan mengarahkan siswa agar terhindar dari konflik interpersonal. Misalnya dengan menerapkan sistem poin, yaitu setiap siswa yang melakukan pelanggaran misalnya berkelahi atau tawuran maka poinnya akan dikurangi, apabila poin habis dalam hal ini disebabkan karena sering berkelahi, maka siswa yang bersangkutan, dapat dikeluarkan dari sekolah.

3. Kepada Keluarga, diharapkan dapat berkoordinasi dengan guru-guru yang ada di sekolah guna melihat perkembangan anak dan mampu mendidik serta mengawasi dengan baik terhadap perilaku anaknya di luar rumah. Orang tua juga dapat menerapkan metode pola asuh yang baik, misal metode pola asuh demokrasi

4. Kepada siswa, agar kiranya menyadari bahwa tujuan utama ke sekolah adalah untuk menuntut ilmu. Karena itu hendaknya setiap pelajar harus menjaga setiap perilakunya baik di dalam lingkungan sekolah maupun di luar lingkungan sekolah, demi kebaikan dirinya sendiri dan keluarganya serta nama baik sekolahnya.

\section{Daftar Pustaka}

Abidin, Z \& Alif Budiono. (2010). Dasar-dasar Bimbingan dan Konseling. Purwokerto: Grafindo Litera Media.

Aminati, Arfiani Yulia. (2013). Studi Kepustakaan Mengenai Landasan Teori dan Praktik Konseling Resolusi Konflik Interpersonal. Jurnal BK UNESA. Vol. 03 No. 01 Tahun 2013.hal 222-235.

Anwar, Zainul. 2015. Strategi Penyelesaian Konflik Antar Teman Sebaya fakultas psikologi Universitas Muhammadiyah Malang. Skripsi. Universitas Muhammadiyah Malang.

Arisuzanti, Pita Kurnia \& Budi Purwoko. (2015). Survey Tentang Konflik Interpersonal Yang Dialami Oleh Siswa Sekolah Menengah Atas (SMA) Negeri Di Surabaya Selatan'. Jurnal BK UNESA. Vol. 04, No. 01, hh 145-151.

Bilqis, Fajar \& Purwoko. (2012). Hubungan Antara Persepsi dam Cara Penyelesaian 
Konflik Interpersonal'. Jurnal BK UNESA Vol. 03, No. 01. Hh 136- 143.

Hendarstin, Refia Julianti \& Budi Purwoko. (2014). Studi Kasus Dinamika Psikologis Konflik Interpersonal Siswa Merujuk Teori Segitiga ABC Konflik Galtung dan Kecenderungan Penyelesaiannya Pada Siswa Kelas XII Jurusan Multi Media SMK Mahardika Surabaya'. Jurnal BK UNESA. Vol. 04, no. 02. Hal 364-374.

Kartono, Kartini. (2011). Patologi sosial 2: Kenakalan Remaja. Jakarta: Rajawali Pers.

Kurniyati, Nurul. (2016). Bimbingan dan Konseling dalam Menangani Konflik Interpersonal Siswa MTs Negeri Maguwoharjo, Depok Sleman Yogyakarta. Skripsi. UIN Sunan Kalijaga.

Lusiawati. (2013). Kecerdasan Emosi dan Penyesuaian Diri pada Remaja Awal yang Tinggal di Panti Asuhan Uswatun Hasanah Samarinda. Jurnal Psikologi. Vol. 1, No. 1. Hh 167-176.

Muslim, Ahmad. (2014). Manajemen Konflik Interpersonal di Sekolah. Jurnal Paedagogy FIP IKIP Mataram Vol. 1, No. 2 hh 124-132.

Ramadhani, Heti Sari. (2016). Kemampuan Resolusi Konflik Interpersonal pada Diri Remaja Setelah Mengikuti Conflict Resolution Outbound Training. Jurnal Psikologi Indonesia. Vol.5, No. 03, hh 187- 193.

Safitri, I \& Budi Purwoko. (2013). Penerapan Layanan Resolusi Konflik Untuk Menangani Konflik Interpersonal Siswa Kelas X-8 SMAN 1 Menganti Gresik'. Jurnal BK Unesa. Vol. 4, No. 01, hh 154159.

Setyana, Dwi Arma. (2012). Pengembangan Paket Menejemen Konflik Untuk Meningkatkan Pemahaman Konflik dan Sikap Positif dalam Menghadapi Konflik Interpersonal siswa'. Jurnal BK. Vol. 4. No. 1, hh. 145151.
Setyono, K \& Heri S. (2015). Faktor-Faktor Determinan Timbulnya Konflik Interpersonal Siswa (Studi Kasus di Kelas XI Jurusan Perawatan Sosial 2). Jurnal BK. Vol. 2. No. 2, hh 94-105.

Shalihin, Ikhwan. (2013). Pengaruh Stres dan Konflik Kerja Terhadap Kinerja Pegawai pada Kantor Kecamatan di Kota Bangun Kabupaten Kutai Kartanegara. Skripsi. Universitas Mulawarman

Subarakah, D.I \& Budi P. (2013). Penerapan Mediasi Sebaya Untuk menangani Konflik Interpersonal Siswa kelas X APK di SMA Ketintang Surabaya'. Jurnal BK. Vol.03, No. 1 hh 373-379.

Sugiyono. (2017). Metodologi Penelitian Kualitatif. Ed-3 Cet 2. Bandung: Alfabeta.

Wirawan. (2009). Konflik dan Manajemen Konflik. Jakarta: Salemba Humanika. 
JURNAL BENING VOLUME 4 NOMOR 2 JUNI 2020

ISSN : 2548-422

E-ISSN : 2716-1765 